\title{
An Empirical Analysis of Globalization-Poverty Nexus: Evidence from Pakistan
}

\author{
Muhammad Tariq Majeed ${ }^{a}$, Sohail Farooq ${ }^{b}$ \\ ${ }^{a}$ Associate Professor of Economics in Quaid-i-Azam University, Islamabad, Pakistan \\ Email: tariq@qau.edu.pk \\ ${ }^{\mathrm{b}}$ Associate Professor of Economics in Hazara University, Mansehra, Pakistan \\ Email: thesohailfarooq@hotmail.com
}

\begin{tabular}{|c|c|}
\hline ARTICLE DETAILS & \multirow{10}{*}{$\begin{array}{l}\text { Despite the significant progress that has been observed towards the } \\
\text { Millennium goals, more than one billion people still live on less than } 1.25 \\
\text { US dollars per day. A large body of the literature has focused on the } \\
\text { growth effects of globalization and generally documents favourable } \\
\text { effects of globalizing on economic growth. Does globalization reduce } \\
\text { poverty? This question has received relatively less attention and the } \\
\text { available evidence is not conclusive. This study investigates the impact } \\
\text { of globalization on poverty in Pakistan using annual time series data } \\
\text { from } 1975 \text { to 2018. The empirical analysis for the effect of globalization } \\
\text { on poverty is based on the ARDL approach to cointegration. The } \\
\text { empirical findings show that globalization exerts a significant adverse } \\
\text { influence on the annual poverty of Pakistan. It implies that the ongoing } \\
\text { process of globalization is leaving the poor of Pakistan behind. } \\
\text { Globalization accentuates not ameliorates poverty and thus marginalizes } \\
\text { the poor of Pakistan. }\end{array}$} \\
\hline History: & \\
\hline Accepted 25 November 2021 & \\
\hline Available Online December 2021 & \\
\hline Keywords: & \\
\hline Globalization; Poverty; & \\
\hline Inequality; Pakistan & \\
\hline JEL Classification: & \\
\hline$F_{21}, F_{41}, J 24$ & \\
\hline DOI: $10.47067 / \mathrm{r}$ & \\
\hline
\end{tabular}

(C) 2021 The authors. Published by SPCRD Global Publishing. This is an open access article under the Creative Commons Attribution-

NonCommercial 4.0

Corresponding author's email address: tariq@qau.edu.pk

\section{Introduction}

Does globalization reduce poverty? This question is highly debated among researchers and policymakers. The available research provides conflicting answers to this question. On the one hand, globalization is considered a solution to poverty while on the other hand globalization is considered a cause of poverty. The studies by Bhagwati and Srinivasan (2002) and Dollar and Kraay (2004) conclude that economic openness increases economic growth which, in turn, reduces poverty. Contrary, Harrison, and McMillan (2007) compile the results of 15 country-specific studies and argue that orthodox perspectives on the linkages between globalization and poverty are misleading, if not downright wrong. They show that the gains from trade are highly unequal and that the poor do not always benefit from globalization. 
Review of Economics and Development Studies, Vol. 7 (4) 2021, 533 - 542

Jeffrey Williamson (2002) points out that "the world has seen two globalization booms over the past two centuries and one bust. The first global century ended with World War I and the second started at the end of World War II, while the years in between were ones of anti-global backlash”. In the first period of globalization, poverty fell from $84 \%$ in 1820 to $66 \%$ in 1910 . In the second period of globalization, poverty fell from $55 \%$ in 1950 to $24 \%$ in 1992 . In the inter-war period, the world population living in poverty remains probably stagnant. The historical negative relationship between globalization and poverty masks variations within and between countries in their experiences with globalization. Many decades of increasing globalization have not yet silenced the debate over the benefits of globalization. The fierce street protests surrounding the ministerial meeting of the WTO and similar protests at the World Bank and the IMF show that the anti-globalization debate is getting strong.

Sala-i-Martin (2002) notes that poverty rates have declined remarkably over the last twenty years. He finds out that the number of one-dollar-a-day poor declined by 235 million between 1976 and 1998. The number of $\$ 2 /$ day poor declined by 450 million over the same period. However, performance across regions has been far from uniform. Specifically, he finds: Asia has undergone dramatic improvements, particularly after 1980. Latin America reduced poverty substantially in the 1970s but that effectively stopped in the 1980s and 1990s. Africa has been a disaster area with respect to poverty as poverty rates in this region have increased substantially over the last thirty years. In Africa, the number of \$2/day poor increased by 227 million and the number of \$1/day poor increased by 175 million over the period 1970-1998. In 1960, 11\% of the world's poor lived in Africa while by 1998 that proportion had risen to $66 \%$.

The literature provides different theories on the distributional and poverty consequences of globalization which can be classified into three categories (Wade, 2001): First, the neoclassical growth theory predicts income convergence across nations in the long run, in response to increased international capital flows. Second, the endogenous growth theory which shows less convergence and, more probable, divergence because diminishing returns to capital are offset by increasing returns to technological innovations. Third, the dependency theory implies that developing countries have relatively limited access to the markets of developed countries and have a narrow exports base. Therefore, international economic integration is less awarding for developing countries and globalization does not cause absolute convergences.

In the presence of such diversified theoretical predictions, estimating the actual impact of globalization on poverty remains largely an empirical issue. Also, no previous effort has been made to quantify the relative contributions of globalization to poverty in Pakistan. In addition, cross-country studies mask the true effects of globalization in a country-specific setting. Therefore, in this study, we focus on the economy of Pakistan to unleash the true impact of globalization on the poor of Pakistan. Pakistan is a low-middle income developing country where more than 60 million people live under the poverty line. Such an alarming figure of poverty is a serious drag on the rapid and sustained economic growth of the economy. This study contributes to the literature by empirically determining the poverty effect of globalization for Pakistan. The analysis is based on annual time series data from 1975 to 2018 and we use the ARDL approach to cointegration.

The rest of the discussion is structured as follows. Section 2 provides a review of the related literature and theoretical links of globalization with poverty. Section 3 describes the data and analytical framework for the study. Section 4 presents a discussion on econometric methodology and estimation procedure. Section 5 puts forward results derived from the research questions and a discussion on these 


\section{Review of Economics and Development Studies, Vol. 7 (4) 2021, 533 - 542}

results. Finally, Section 6 concludes the discussion.

\section{Theoretical Links of Globalization and Poverty}

There are various channels through which globalization can affect poverty. In the literature, the main link of globalization with the poor is described through the implications of the Heckscher-Ohlin (HO) model. According to the model, a nation will specialize in a product that requires intensive use of its abundant factors of production. Since developing countries are abundant in low-skilled labour demand for abundant labour will increase their wages, thereby decreasing wage inequality and poverty.

The HO model predicts a lower inequality and poverty with the assumption of identical technologies across countries. However, if this assumption is dropped then trade effects also depend on technology diffusion from developed countries to developing countries that generate a skill premium and increase the demand and wages of high-skilled labour. Thus trade makes wage distribution more unequal (see, for example, Berman et. al., 1994; Autor et. al., 1998). Davis and Mishra (2007) argue that the implication of the HO model that trade liberalization increases the wages of unskilled labour is 'worse than wrong'. They show that such implication is based on a very narrow interpretation of the Stolper-Samuelson (SS) theorem. The SS theorem holds under the following conditions: 1) if all countries produce all goods; 2) if goods produce at home and abroad are close substitute, or 3) if comparative advantage can be fixed vis-à-vis all trading partners.

Moreover, the empirical evidence from developing economies such as India and Poland suggests that labour is not as mobile as the HO model considers. In real life, there are too many barriers to labour mobility for workers. Another reason that the poor of developing economies may not gain from trade is that they work in those sectors which are historically protected such as textile and apparel. Trade reforms may result in less protection for unskilled workers. One strand of the literature suggests that globalization helps to eradicate poverty when complementary policies are in place. For instance, a case study of Gambia shows that the poor farmers only expected to benefit from greater excess to export markets if they access complementary inputs such as credit support and technical know-how. Some studies also highlight the importance of the social safety net as complementary input. For instance, if the farmers of Mexico have not received income support from the government their incomes would have been halving during the 1990 .

The impact of globalization on the poor also depends on how globalization is measured. Some studies show that globalization in the form of exports growth and foreign investment inflows help to reduce the poverty. For instance, Harrison and McMillan (2007) show evidence that poverty has fallen in regions where exports or foreign investment increased. Contrary to this, financial globalization can have a diverse impact on the poor. FDI decreases poverty while financial inflows increase poverty. Financial globalization enhances the risk of financial crises and the poor are more vulnerable to the financial crisis. In the case of Indonesia poverty rates increases at least 50\% after the currency crisis in 1977. Cross-country evidence shows that financial integration causes higher consumption and output volatility in low-income developing countries. Financial integration can help to ameliorate poverty if strong institutions more stable policies hold in financial integrating economies. However, developing economies lack these strengths. On the one hand, unrestricted capital flows increase poverty, on the other hand, FDI inflows are associated with a reduction in poverty.

It is noteworthy that globalization produces both winners and losers among the poor. Even in the same region, two sets of farmers producing the same good may be affected in diverse directions. For instance, in Mexico, small and medium corn farmers' income fell by half in 1990, while the income of 


\section{Review of Economics and Development Studies, Vol. 7 (4) 2021, 533 - 542}

large corn farmers increased. In a case study of Brazil, Carneiro and Arbache (2003) find out that trade liberalization may not be sufficient to significantly reduce poverty. In another case study of Papua New Guinea, Gibson (2000) finds out that poverty increased during the 1990s. In a recent study, Majeed (2010) finds that trade accentuates, not ameliorates, and that it intensifies, not diminishes, poverty in the case of Pakistan.

In the case of Mexico, evidence shows that firms demand more white-collar workers in exporting sectors as compared to non-exporting sectors of production. Thus exports cause an adverse effect on inequality (Hanson and Harrison, 1999). Moreover, Berman and Machine (2004) confirm this positive relationship between exports and inequality for developing countries. These models establish a positive relationship between trade and inequality but do not provide a direct link between trade and poverty. It is also pointed out in some survey studies that the relationship between globalization and poverty has been assessed indirectly (Winters et al., 2004; Goldberg and Povcnick, 2006; Ravallion, 2004). Our study establishes a direct relationship between globalization and poverty.

Some recent studies suggested conflicting evidence of different measures of globalization on poverty. Khan and Majeed (2018) investigated globalization and poverty nexus for113 developing countries from 1980 to 2014. Their findings suggest that globalization reduces poverty. However, political globalization is not helpful in poverty reduction. Dhrifi et al. (2020) show the poverty-reducing effect of FDI in a sample of 98 developing economies from 1995 to 2017. Anetor et al. (2020) explored the impact of trade and FDI on poverty using panel data of 29 Sub-Saharan economies from 1990 to 2017. Their findings suggest that FDI has a negative impact on poverty reduction while trade has a positive impact on poverty reduction. Dada and Akinlo (2021) explored the influence of FDI on poverty in sub-Saharan Africa over the period for the period 1986-2018. Their findings suggest that The FDI increases poverty at a higher degree of environmental degradation. These studies provide panel data evidence that cannot be generalized for an individual economy.

Since globalization is a multidimensional and complex phenomenon, a simple focus on a specific aspect of globalization can give misleading results. It is also evident from the above-discussed literature that different forms of globalization exert conflicting effects on the poor of developing economies. One possible solution to this problem is to analyse the marginalization of the poor in relation to a comprehensive measure of globalization. The present study considers various forms of globalization and uses an overall index of globalization to determine its poverty effect in the case of Pakistan.

\section{Data and Modeling}

We incorporate the globalization index in the poverty model to estimate the poverty impact of the overall globalization process in the economy of Pakistan. Some other variables are also important for the poverty model that needs to be controlled to avoid specification bias. These are the Gini coefficient, education, financial development, and economic growth.

In order to build a poverty model, this study follows a basic poverty-growth model suggested by Ravallion (1997). In this study, data is extracted from the Government of Pakistan (various issues) and from World Development Indicators (WDI) over the period 1975-2013. The annual time series data on poverty, Gini coefficient and education is derived from Government of Pakistan while the data on GDP, financial development has been derived from WDI (2015). The data on globalization index is derived from KOF index based on Dreher et al., (2008). 
The general functional form of our model is as follows:

$\operatorname{Pov}_{t}=Y_{t} G I N I_{t} E_{d u} F_{t} G l o b_{t}$

We use log-liner specification for empirical purpose because it provides efficient results and also convenient to interpret parameters estimated. The functional form of growth model is constructed as follows:

$\ln \operatorname{Pov}_{t}=\gamma_{0}+\gamma_{1} \ln Y_{t}+\gamma_{2} \ln G I N I_{t}+\gamma_{3} \ln E d u_{t}+\gamma_{4} \ln F_{t}+\gamma_{5} G l o b_{t}+\varepsilon_{i}$

Where, $\ln Y_{t}$ is the natural $\log$ of real GDP per capita, $\ln G I N I_{t}$ is the natural $\log$ of Gini coefficient, Ft is the financial development, and $\ln G l o b_{t}$ is the natural of globalization and $\varepsilon_{i}$ is the error term which is normally distributed with zero mean and constant variance.

\section{Econometric Methodology}

For empirical analysis, we use the ARDL approach to cointegration. One of the advantages of the ARDL approach is that it does not require the same level of integration for all variables. It does not matter whether variables are integrated of order zero or they are integrated of order one or they have a mix order of integration. This feature of ARDL gives it an edge over standard cointegration techniques. In the case of mixed order of integration standard cointegration techniques become unstable because the power of the test to determine cointegration becomes low. The only condition for ARDL is that no variable should be integrated of order two.

The ARDL method is based on two steps. First, the long-run relationship between variables is tested using F-statistic. F-statistic is used to test the significance of the lagged levels of the variables in the unrestricted error correction model (ECM). Second, the parameter estimates of the error correction model of the long-run relationship are obtained. The ECMs corresponding to the globalization-poverty relationship (2) is provided below as equation (3).

$\Delta \operatorname{lnPov} \operatorname{Po}_{t}=\gamma_{1}+\gamma_{T} T+\gamma_{Y} \operatorname{lnPov_{t-1}}+\gamma_{L} \ln Y_{t-1}+\gamma_{K} \ln G I N I_{t-1}+\gamma_{p} \ln E d u_{t-1}+\gamma_{F} \ln F_{t-1}+$ $\gamma_{G L} \ln G l o b_{t-1}+\sum_{i=1}^{r} \gamma_{i} \Delta \ln P o v_{t-i}+\sum_{j=0}^{s} \gamma_{j} \Delta \ln Y_{t-j}+\sum_{k=0}^{t} \gamma_{k} \Delta \ln G I N I_{t-k}+\sum_{p=0}^{q} \gamma_{p} \Delta \ln E d u_{t-l}+$ $\sum_{l=0}^{u} \gamma_{l} \Delta \ln F_{t-l}+\sum_{m=0}^{v} \gamma_{m} \Delta \operatorname{lnGlob} b_{t-m}+\varepsilon_{i}$ (3)

Where $\Delta$ is the first difference operator or change between two consecutive periods

We test the presence of the long-run relationship between variables using-F statistics. We test the following hypothesis. The null hypothesis that the long-run relationship does not hold between variables meaning that that the coefficients of the lagged variables are simultaneously equal to zero. While the alternative hypothesis is that the long-run relationship holds between variables suggesting that at least one of these coefficients is not equal to zero.

$\mathrm{H}_{\mathrm{o}}=\gamma_{\mathrm{k}}=\mathrm{o}$ for all $\mathrm{k}$

$\mathrm{H}_{1}=\gamma_{\mathrm{k}} \neq \mathrm{O}$ for at least one $\mathrm{k}$

The distribution of F-statistics is non-standard which depends on the orders of integration of the variables comprised in the ARDL model. The critical values given by Pesaran et al. (2001) are used to compare with the computed F-statistics. This gives three possible outcomes of the long-run relationship 
between variables. First, if F-statics is lesser than the lower-bound critical value the null hypothesis of no long-run relationship is accepted. It implies that variables included in the ARDL model do not have a long-run relationship. Second, if F-statics is larger than the upper-bound critical value then the null hypothesis of no long-run relationship is rejected suggesting that the long-run relationship holds between variables included in the ARDL model. Third, if F-statics is larger than the lower bound but smaller than the upper-bound then null hypothesis of no long-run relationship remains indecisive.

\section{Empirical Results}

\subsection{Unit root test}

As a first step of estimation procedure, we test time series properties of the data using the standard unit root tests the augmented Dickey-Fuller (ADF) and Phillips-Perron (PP) tests. The basic purpose of unit root tests is to ensure that no series is integrated of order two. Table 1 exhibits the results of ADF and PP tests. The results reported in Table 1 show that all variables are integrated of order one at $5 \%$ level of significance except the variables of inflation which is level stationary at $1 \%$ level of significance. Nevertheless none of the series is integrated of order two suggesting that the basic requirements of ARDL procedure are met and we can safely move on the next step of the estimation.

Table 1: Results of ADF and PP tests

\begin{tabular}{|c|c|c|c|c|c|c|}
\hline \multirow[t]{2}{*}{ Variables } & \multicolumn{2}{|c|}{ ADF test statistics } & \multicolumn{2}{|c|}{ PP test statistics } & \multirow{2}{*}{$\begin{array}{l}\text { Order of } \\
\text { integration } \\
\text { (at } 5 \% \text { level } \\
\text { of } \\
\text { significance) }\end{array}$} & \multirow{2}{*}{$\begin{array}{l}\text { Order of } \\
\text { integration } \\
\text { (at } 10 \% \text { level } \\
\text { of } \\
\text { significance) }\end{array}$} \\
\hline & Level & $\begin{array}{l}\text { First } \\
\text { difference }\end{array}$ & Level & $\begin{array}{l}\text { First } \\
\text { difference }\end{array}$ & & \\
\hline $\begin{array}{ll}\text { GDP } & \text { per } \\
\text { Capita } & \end{array}$ & $\begin{array}{l}-2.09 \\
(0.53)\end{array}$ & $\begin{array}{l}-0.67^{*} \\
(0.003)\end{array}$ & $\begin{array}{l}-1.80 \\
(0.69)\end{array}$ & $\begin{array}{l}-0.67^{*} \\
(0.003)\end{array}$ & $\mathrm{I}(1)$ & $\mathrm{I}(1)$ \\
\hline Globalization & $\begin{array}{l}-1.88 \\
(0.64) \\
\end{array}$ & $\begin{array}{l}-5.65^{*} \\
(0.000)\end{array}$ & $\begin{array}{l}-2.00 \\
(0.58) \\
\end{array}$ & $\begin{array}{l}-5.68 * \\
(0.000)\end{array}$ & $\mathrm{I}(1)$ & $\mathrm{I}(1)$ \\
\hline Education & $\begin{array}{l}-2.06 \\
(0.55)\end{array}$ & $\begin{array}{l}-5.27^{*} \\
(0.000)\end{array}$ & $\begin{array}{l}-2.38 \\
(0.38)\end{array}$ & $\begin{array}{l}-5.27^{*} \\
(0.000)\end{array}$ & $\mathrm{I}(1)$ & $\mathrm{I}(1)$ \\
\hline Inequality & $\begin{array}{l}-2.12 \\
(0.51)\end{array}$ & $\begin{array}{l}-5.59^{*} \\
(0.000)\end{array}$ & $\begin{array}{l}-2.21 \\
(0.47)\end{array}$ & $\begin{array}{l}-5.61^{*} \\
(0.000)\end{array}$ & $\mathrm{I}(1)$ & $\mathrm{I}(1)$ \\
\hline Inflation & $\begin{array}{l}-4.53 \\
(0.004)\end{array}$ & $\begin{array}{l}-8.89^{*} \\
(0.000)\end{array}$ & $\begin{array}{l}-4.58 * * \\
(0.004)\end{array}$ & $\begin{array}{l}-8.94^{*} \\
(0.000)\end{array}$ & $\mathrm{I}(\mathrm{O})$ & $\mathrm{I}(\mathrm{O})$ \\
\hline $\begin{array}{l}\text { Financial } \\
\text { Development }\end{array}$ & $\begin{array}{l}-1.42 \\
(0.84) \\
\end{array}$ & $\begin{array}{l}-5.6^{\star} \\
(0.000)\end{array}$ & $\begin{array}{l}-1.71 \\
(0.73)\end{array}$ & $\begin{array}{l}-5.6 \\
(0.000)\end{array}$ & $\mathrm{I}(1)$ & $\mathrm{I}(1)$ \\
\hline Poverty & $\begin{array}{l}-2.38 \\
(0.39)\end{array}$ & $\begin{array}{l}-4.57^{*} \\
(0.004)\end{array}$ & $\begin{array}{l}-2.20 \\
(0.47)\end{array}$ & $\begin{array}{l}-4.55^{*} \\
(0.004)\end{array}$ & $\mathrm{I}(1)$ & $\mathrm{I}(1)$ \\
\hline
\end{tabular}

Note: The test statistics significant at $5 \%$ and $10 \%$ levels of significant are indicated by * and ** respectively.

\subsection{Bound test for cointegration}

In the next step of ARDL model, we estimate equations (3) and (4) to determine the long-run relationship between variables. To determine the optimal number of lags, we use Schwarz Bayesian Criterion (SBC). Our estimated model satisfies different diagnostic tests which have been reported in Table 2. The LM test for serial correlation indicates our empirical findings are not plagued with the problem of serial correlation. For heteroscedasticity the White test is applied which also shows that our 
results are not suffering from the problem of heteroscedasticity. The Ramsey RESET test is applied to check the functional form and it is clear from the test that our model is clearly specified. Finally, we apply Jarque-Bera test to test the normality of residuals which also shows that the residuals are normally distributed. The results of bounds tests for equations 3 are reported in Table 3. The Fstatistics of bound tests indicate that in the inequality growth specification the calculated F-statistics is larger than the upper bound critical value. It implies that the long-run relationship exists in growth inequality equation.

\section{Table 2: Results of diagnostic tests}

\begin{tabular}{|l|l|l|}
\hline Test statistics & \multicolumn{2}{l|}{ Model 1 (Eq. 2) } \\
\hline & F-statistics & Probability \\
\hline Lagrange multiplier test for serial correlation & 1.72 & 0.20 \\
\hline White test for heteroscedasticity & & \\
\hline Ramsey's RESET for functional form & 0.62 & 0.71 \\
\hline Jarque-Bera test for normality & 1.72 & 0.20 \\
\hline
\end{tabular}

Table 3: F-Statistics for cointegration relationship

\begin{tabular}{|l|l|l|l|l|}
\hline The model & $\begin{array}{l}\text { Computed } \\
\text { F-statistics }\end{array}$ & \multicolumn{2}{|l|}{$\begin{array}{l}\text { Critical F-statistics at 5\% } \\
\text { level }\end{array}$} & Outcome \\
\hline & $\begin{array}{l}\text { Lower } \\
\text { bound }\end{array}$ & Upper Bound & \\
\hline Fy (Pov/ GDP, Ineq, Edu, FD, Glo) & 5.32 & 2.84 & 4.29 & Cointegration \\
\hline
\end{tabular}

*The critical values are taken from Pesaran et al. (2001), Table CI (iii), Case 111: unrestricted intercept and no trend.

\subsection{Poverty and Globalization}

Our poverty globalization model confirms the long run relationship. In the next step of empirical analysis, we present short run and long run parameter estimates for poverty model developed in equation 3. The parameter estimate on poverty is positive and significant at one percent level of significance both in the short-run and long-run. This empirical finding is consistent with the theoretical studies on poverty and globalization (Davis and Mishra (2007). This finding implies that absolute poverty increases as globalization proceeds. The coefficient of ECM term is -0.59 and statically significant at 5 percent level of significance. It implies that 59\% error correction will take place towards equilibrium each year. 
Review of Economics and Development Studies, Vol. 7 (4) 2021, 533 - 542

Table 4: Short-run relationship

\begin{tabular}{|c|c|c|c|c|}
\hline \multicolumn{5}{|l|}{ Cointegrating Form } \\
\hline Variable & Coefficient & Std. Error & t-Statistic & Prob. \\
\hline$\Delta$ Povertyt-1 $_{\mathrm{t}}$ & 0.418891 & 0.106223 & $3 \cdot 943493$ & 0.0007 \\
\hline$\Delta$ GDP per capita & -0.758501 & 0.622942 & -1.217611 & 0.2369 \\
\hline$\Delta$ GDP per capita $_{\mathrm{t}-1}$ & 2.585985 & 1.105802 & 2.338561 & 0.0293 \\
\hline$\Delta$ Income inequality & -0.087199 & 0.066964 & -1.302169 & 0.2070 \\
\hline$\Delta$ Globalization & 1.140936 & 0.499489 & 2.284205 & 0.0329 \\
\hline$\Delta$ Globalization $_{\mathrm{t}-1}$ & 0.962809 & 0.258711 & 3.721555 & 0.0013 \\
\hline$\Delta$ Education & -0.050336 & 0.068696 & -0.732745 & 0.4718 \\
\hline$\Delta$ Financial dev. & -0.322035 & 0.233418 & -1.379650 & 0.1822 \\
\hline$\Delta$ Financial dev.t-1 & 0.322001 & 0.193914 & 1.660536 & 0.1117 \\
\hline CointEq(-1) & -0.594678 & 0.147578 & -4.029572 & 0.0006 \\
\hline
\end{tabular}

Table 5: Long-run relationship

\begin{tabular}{|l|l|l|l|l|}
\hline Long Run Coefficients & Coefficient & Std. Error & t-Statistic & Prob. \\
\hline Variable & & & & \\
\hline GDP per capita & -0.941097 & 0.543387 & -1.731907 & 0.0980 \\
\hline Income inequality & 0.424875 & 0.169612 & 2.504977 & 0.0206 \\
\hline Globalization & 1.330969 & 0.303373 & 4.387238 & 0.0003 \\
\hline Education & -0.321930 & 0.117232 & -2.746108 & 0.0121 \\
\hline Financial dev. & -0.376565 & 0.262040 & -1.437052 & 0.1654 \\
\hline Constant & 7.256082 & 1.895492 & 3.828073 & 0.0010 \\
\hline
\end{tabular}

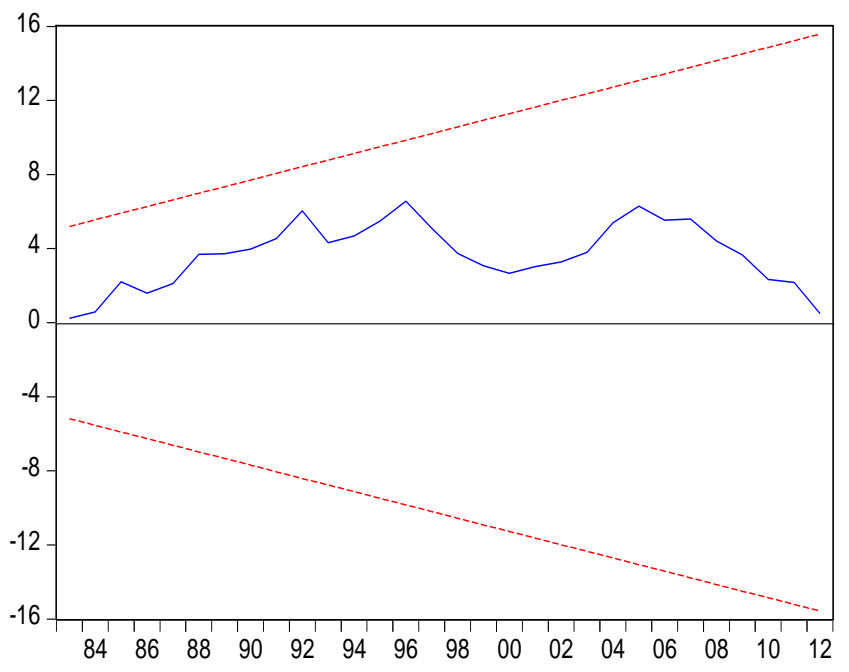

Figure 1 CUSUM Test

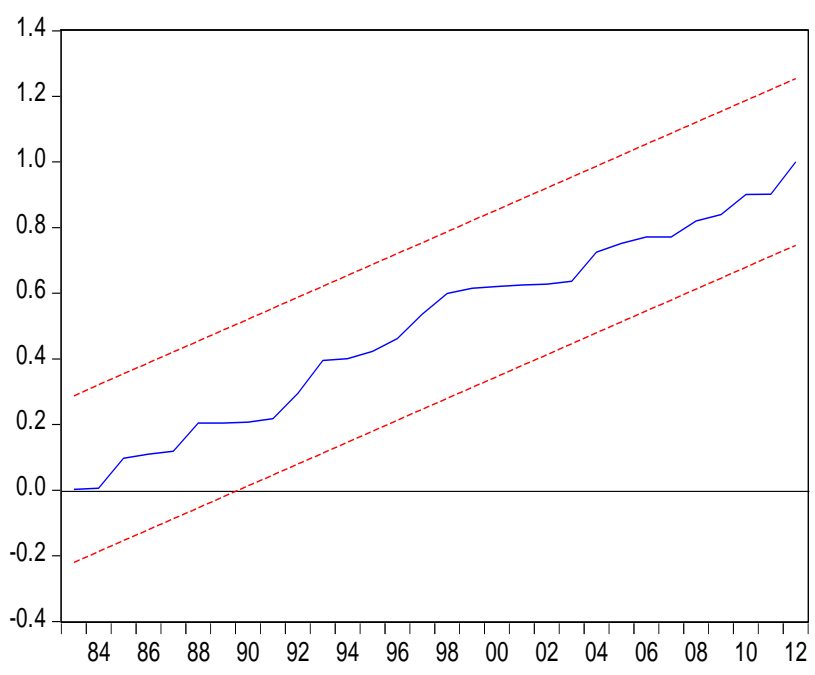

- CUSUM of Squares ----. 5\% Significance

Figure 2 CUSUM Square Test 
Review of Economics and Development Studies, Vol. 7 (4) 2021, 533 - 542

\subsection{Stability Tests}

We apply cumulative sum of recursive residual (CUSUM) and the cumulative sum of square of recursive residual (CUSUMSQ) tests to check the stability of the model. The figure 1 and 2 shows the plots for CUSUM and CUSUMSQ, respectively. Both figures show that the estimated line is well within the critical limits at a 5 percent level of significance implying that model is stable and reliable.

\section{Conclusion}

The purpose of this study has been to assess the poverty effects of globalization for Pakistan over a long period 1975 to 2018 . The empirical analysis for the effect of globalization on poverty is based on the ARDL approach to cointegration. The empirical findings show that globalization exerts significantly adverse influence on annual poverty of Pakistan. It implies that ongoing process of globalization is marginalizing the poor of Pakistan and leaving them behind. Contrary to this, economic growth and education are the key sources which help to reduce poverty in the case of Pakistan.

Since globalization accentuates not ameliorates poverty in the case of Pakistan, it has important policy implications. Leaving the poor segment of society on market forces and international integration may increase their sufferings and vulnerabilities. It is necessary that complimentary policies such as investment in human capital, reforms in financial sector, improvement in labour laws need to be placed as complimentary priorities while proceeding for globalization.

Future studies can focus on multidimensional poverty as it is more comprehensive measure of poverty. This research mainly established a direct association between globalization and poverty whereas future studies can explore the indirect effects of globalization on poverty. This study assumes a symmetric association between globalization and poverty while future studies can focus on asymmetric relationships between globalization and poverty.

\section{References}

Anetor, F. O., Esho, E., \& Verhoef, G. (2020). The impact of foreign direct investment, foreign aid and trade on poverty reduction: Evidence from Sub-Saharan African countries. Cogent Economics \& Finance, 8(1), 1737347.

Autor, D., Katz, L., \& Krueger, A. B. (1998). Computing inequality: have computers changed the labor market? Quarterly Journal of Economics, 113, 1169-1214.

Berman, E., \& Machin, S. (2004). Globalization, skill-biased technological change and labour demand. In E. Lee, \& M. Vivarelli (Eds.),Understanding Globalization, Employment and Poverty Reduction (pp. 39-66). New York: Palgrave Macmillan.

Berman, E., Bound, J., \& Griliches, Z. (1994). Changes in the demand for skilled labor within U.S. manufacturing industries. Quarterly Journal of Economics, 109, 367-398.

Bhagwati, Jagdish, \& Srinivasan, T. N. (2002). Trade and poverty in the poor countries. American Economic Review, 92(2), 180-183.

Carneiro, F. and Arbache, J. (2003). Assessing the impacts of trade on poverty and inequality. Applied Economics Letter, 10, 989-94.

Dada, J. T., \& Akinlo, T. (2021). Foreign direct investment and poverty reduction in sub-Saharan Africa: does environmental degradation matter? Future Business Journal, 7(1), 1-10.

Davis, D. R., \& Mishra, P. (2007). Stolper-Samuelson is dead: And other crimes of both theory and data. In Globalization and poverty (pp. 87-108). University of Chicago Press.

Dhrifi, A., Jaziri, R., \& Alnahdi, S. (2020). Does foreign direct investment and environmental degradation matter for poverty? Evidence from developing countries. Structural Change 
and Economic Dynamics, 52, 13-21.

Dollar, David, \& Kraay, Aart (2004). Trade, growth and poverty. The Economic Journal, 114(493), F22-F49.

Dreher, Axel, Gaston, Noel, \& Martens, Pim (2008). Measuring globalization: Gauging its consequences. Springer.

Gibson, J. (2000).The impact of growth and distribution on poverty in Papua New Guinea. Applied economics Letters, 7, $605-607$

Goldberg, P., Pavcnik, N. (2006). The effects of the Colombia trade liberalization on urban poverty. In: Harrison, A. (ed.) Globalization and Poverty. University of Chicago Press for National Bureau of Economic Research, Chicago, IL

Harrison, A., \& Hanson, G. (1999). Who gains from trade reform? Some remaining puzzles. Journal of development Economics, 59(1), 125-154.

Harrison, A., \& McMillan, M. (2007). On the links between globalization and poverty. The Journal of Economic Inequality, 5(1), 123-134.

Khan, F. N., \& Majeed, M. T. (2018). Globalization and Poverty Nexus: A Panel Data Analysis. Forman Journal of Economic Studies, 14, 143-174.

Majeed, M Tariq (2010). Poverty and Employment: Empirical evidence from Pakistan. The Forman Journal of Economic Studies, Vol. (6)

Ravallion, M. (1997). Can high inequality developing countries escape absolute poverty? Economics Letters, 56, 51-7.

Ravallion, M. (2004). Pro-poor growth: a primer. World Bank Policy Research Working Paper No. 3242.

Sala-i-Martin, Xavier (2002). The world distribution of income (estimated from individual country distributions), mimeo Columbia University.

Wade, R.H. (2001). Is globalisation making the world income distribution more equal? Working Paper Series, No. 10, Development Economics Studies Institute, London School of Economics.

Williamson, Jeffrey (2002). Winners and losers over two centuries of globalization,' WIDER Annual Lecture 6, UNU/WIDER, Helsinki.

Winters, L. Alan, McCulloch, Neil and McKay, Andrew (2004). Trade liberalization and poverty: the evidence so far. Journal of Economic Literature, 42 (1), 72-115. 